\title{
A guide to nanosafety testing: considerations on cytotoxicity testing in different cell models
}

Christian Riebeling ${ }^{{ }^{*}}$, Jean-Pascal Piret ${ }^{{ }^{*}}$, Bénédicte Trouiller ${ }^{3^{*}}$, Inge Nelissen ${ }^{4^{*}}$, Christelle Saout $^{2}$, Olivier Toussaint ${ }^{2 \dagger}$, Andrea Haase $^{1 \#}$

1) German Federal Institute for Risk Assessment (BfR), Department of Chemical and Product Safety, Berlin, Germany

2) University of Namur, Namur Research Institute for Life Sciences (NARILIS), Namur Nanosafety Center (NNC), Research Unit in Cellular Biology (URBC), Namur, Belgium 3) Institut National de l'Environnement Industriel et de Risques (INERIS), Experimental Toxicology Unit, Verneuil-en-Halatte, France

4) Flemish Institute for Technological Research (VITO), Environmental Risk and Health Unit, Mol, Belgium

* authors contributed equally

\#Correspondence should be addressed to:

Dr. Andrea Haase

German Federal Institute for Risk Assessment (BfR)

Department of Chemical and Product Safety

Max-Dohrn-Strasse 8-10

10589 Berlin

Germany

phone: $\quad+4930184123423$

fax: $\quad+49301841263423$

e-mail: $\quad$ andrea.haase@bfr.bund.de 


\section{Abstract}

Safety testing of nanoparticles (NPs) relies on robust, predictive, and reproducible methods. Integrated test strategies usually start with the assessment of in vitro cytotoxicity. Methods for this purpose are only partially established for NPs. The aim of this study was to evaluate three cytotoxicity assays for their applicability to NPs in several human cell models representing the most important NP target organs and to compare cell responses. The assays covered different biological principles, i.e. ATP content, redox metabolism, and membrane permeability, as well as different read-out principles, i.e. luminescence, colorimetry, and fluorescence. For all assays standard operating procedures were developed. A549 and NCl-H441 lung epithelial cells in single and in co-culture with THP-1 derived macrophages served as lung epithelial models. Normal human epidermal keratinocytes and in vitro reconstituted human epidermis were employed as skin models. Naïve and differentiated Caco-2 gut epithelial cells were applied as gut epithelial models. Primary CD34-derived dendritic cells (CD34-DCs) served as an immune model. We used well-characterized model NPs, i.e. $50 \mathrm{~nm}$ amine-modified and $40 \mathrm{~nm}$ carboxyl-modified polystyrene NPs (PS- $\mathrm{NH}_{2}$ and PS-COOH, respectively).

PS-COOH NPs showed no effect in any test while PS-NH $\mathrm{N}_{2}$ displayed cytotoxicity in most cell models. CD34-DCs was the most sensitive cell model tested. The tetrazolium-based MTS assay was the most robust assay in our study, applicable to all cell models investigated. Therefore, this assay could become an integral part of a NP testing strategy. Other assays might be also useful, depending on the cell model or the type of investigation.

Keywords: Nanoparticles, cytotoxicity, cell viability, reproducibility 


\section{Introduction}

The development of in vitro methods for toxicological testing of nanoparticles (NPs) is a major research endeavor. NPs can be synthesized in many different variants by varying size, shape or by applying chemical surface modifications. Therefore in order to save costs and time and to reduce animal testing reliable in vitro methods are urgently needed to screen for hazardous NPs, to prioritize NPs for further testing and also to obtain initial data for risk assessment. Most toxicological endpoints require prior knowledge of the acute toxicity of the test compound. Many pathways of (regulated) cell death have evolved in multicellular organisms. Some can be specific for certain cell types and/or stimuli, including several types of regulated necrosis and apoptosis (Galluzzi et al. 2014; Green et al. 2014). While mechanistic insight is important in some cases, a mechanism-independent measurement often gives an initial starting point for more elaborate testing. In vivo, many forms of cell death (e.g. apoptosis) lead to early removal of the dying cells by macrophages. However, in vitro, in the absence of macrophages, all forms of cell death will eventually cause loss of integrity of the cellular membrane. Certain dyes such as trypan blue and propidium iodide will cross only compromised membranes and can be used to specifically stain dead cells. In addition, the concomitant release of cytosolic enzymes into the cell culture medium can be used as a read-out since the released enzyme activity correlates with the extent of membrane rupture and therefore is a measure for cell death. Most often lactate dehydrogenase (LDH) activity is measured in cell culture medium using the $\mathrm{NADH}$ dependent conversion of a dye (Korzeniewski and Callewaert 1983). Another approach is the measurement of the number of viable cells after treatment. Arguably the most popular method is based on the reduction of a tetrazolium salt to a colored formazan salt derivative by cellular $\mathrm{NAD}(\mathrm{P}) \mathrm{H}$-dependent oxidoreductase enzymes, introduced by Mosmann (1983). The reduction of 3-(4,5-dimethylthiazol-2-yl)-2,5-diphenyltetrazolium bromide (MTT) represents a measure for the cellular metabolic capacity and correlates with the number of cells (Mosmann 1983). Oxidoreductases responsible for the dye reduction are mainly located in the cytoplasm, i.e. in the endosomal/ lysosomal compartment and at the plasma 
membrane, and are also partly associated with oxidative phosphorylation in mitochondria (Stepanenko and Dmitrenko 2015). Meanwhile a couple of assays using similar dyes such as MTS, WST or XTT are available as well. In some forms of cell death such as apoptosis mitochondria play an important role. During apoptosis cellular proteins involving the proapoptotic bcl-2 family disrupt mitochondrial function (Galluzzi et al. 2014; Green et al. 2014). In other forms of cell death such as necrosis, loss of mitochondrial function and of oxidoreductases is a later event coinciding with plasma membrane rupture (Aki et al. 2015; Green et al. 2014). Thus, dyes, that accumulate in mitochondria to test their function can be used as well to assess cell viability (Petronilli et al. 2001). Finally, metabolic capacity can also be measured by determination of the intracellular ATP content using luciferase or other ATP consuming reactions (Kangas et al. 1984). Viable cells under normal culture conditions maintain a relatively constant amount of ATP. It is assumed that the capacity for ATP synthesis is lost early during cell death and remaining ATP is rapidly used up or eliminated by ATPases.

For cytotoxicity measurements it would be optimal to use non-dividing cells as otherwise it may become difficult to distinguish effects on cell viability from effects on cell proliferation. However, often this is not possible. Thus, it is very important to understand and to precisely describe how a particular assay is performed, as this affects the interpretation of the results. Furthermore, cytotoxicity should be assessed under similar conditions (i.e. concentrations, time points) as other toxicological endpoints of interest, which might be exploited later on in the test strategy.

It should be noted that specific issues arise when testing cytotoxic effects of NPs in vitro. In particular, enzyme- and dye-based assays need to be carefully checked for possible interferences from NPs. Assay reagents might react or be immobilized on the NP's surface. Especially assays using spectrophotometric read-out might be impaired as NPs can scatter or absorb light or exhibit interfering plasmon resonance (Bonvin et al. 2017; Kroll et al. 2012; Monteiro-Riviere et al. 2009; Stone et al. 2009; Tournebize et al. 2013). Several consortia have already worked on evaluation and harmonization of cytotoxicity assays for NPs (Elliott 
et al. 2017; Piret et al. 2017; Rösslein et al. 2015; Xia et al. 2013). Moreover, a standard assay specifically dedicated to NPs is currently in preparation using the MTT variant 3-(4,5dimethylthiazol-2-yl)-5-(3-carboxymethoxyphenyl)-2-(4-sulfophenyl)-2H-tetrazolium (MTS) assay as an in vitro cytotoxicity assay (ISO/AWI 19007 Modified MTS assay for measuring the effect of NPs on cell viability, ISO, Geneva, Switzerland). In this study we decided to further explore three assay types. As a late response assay the LDH assay was chosen. For an earlier response assay the MTS assay was chosen. Finally, ATP level measurements were selected as an early marker of cellular stress.

In toxicology, automated testing based on high-throughput screening (HTS) or high-content screening (HCS) is becoming increasingly important (Hartung 2008, Judson et al. 2013). It may be considered that in the future HTS/ HCS might be an integral part of the decisionmaking tools used routinely for the toxicity screening of chemicals, as well as NPs (Judson et al. 2013). Thus, another goal of this study was to identify assays which can be used in HCS approaches to investigate the cytotoxicity of NPs. The cell membrane impermeable TOPRO nucleic acid stain may be considered as an LDH equivalent assay for an HCS approach (Anguissola et al. 2014). As an HCS equivalent for the MTS assay cyanine monomers as nucleic acid counterstains such as TO-PRO-1/3/5 and similar dyes may be considered (Anguissola et al. 2014). For the ATP assay we have not identified an HCS equivalent. To generate data relevant to toxicological problems, the route of exposure should be taken into account. In terms of potential NP hazards, inhalation has been identified as the most important exposure route. Experimental studies suggest that NPs can cross from the lung into the bloodstream (Balasubramanian et al. 2013; Kendall and Holgate 2012; Kreyling et al. 2014). Cutaneous and oral exposure to NPs, which may be a fraction of bulk materials and not necessarily specifically engineered NPs, are already commonplace for some materials such as silica and titanium dioxide (Peters et al. 2012; Weir et al. 2012). Historical data for oral intake of these materials show no adverse effects (Lewinson et al. 1994; Martin 2007; Skocaj et al. 2011). Dermal penetration is considered negligible at least for healthy skin and for the most commonly used metal and metal oxide NPs (Labouta and Schneider 2013; 
Nohynek and Dufour 2012; Piret et al. 2014). In the case that NPs breach the barriers of the first-line exposure organs, blood and lymphatic system are usually the first compartments reached, prior to secondary organs such as liver and kidney. In order to take into account different possible routes of exposure we tested several widely used cell lines representing first-line exposed organs, skin, intestinal tract and respiratory tract, and also the immune system. A549 and $\mathrm{NCl}-\mathrm{H} 411$ are epithelial cells derived from human, male, lung carcinomas, and were used to represent lung epithelial models. A549 cells have an alveolar type II-like phenotype (Foster et al. 1998) and NCl-H411 exhibit both alveolar (i.e. type II cell) and bronchiolar (i.e. club cell) epithelial phenotype (Hermanns et al. 2004; Salomon et al. 2014). Caco-2 cells are epithelial cells derived from human, male, colorectal adenocarcinoma. These cells can undergo enterocytic differentiation (Jumarie and Malo 1991; Piret et al. 2012) and represent the gastro-intestinal tract in this study. THP-1 cells are monocytes derived from human, male, acute monocytic leukaemia, and can be differentiated into macrophage-like cells (Chanput et al. 2014).

Generally, primary cells are considered to closer resemble the in vivo phenotype while cell lines are mostly of tumor origin and/or virus-transformed. Therefore, in this study we also included two primary cell types. Normal human epidermal keratinocytes (NHEK) from a pool of three donors were used as skin in vitro model. CD34 dendritic cells (CD34-DCs) were derived through differentiation of progenitor cells from different human cord blood donors. Dendritic cells are part of the immune system; they process antigen material and present it on the cell surface to the T cells of the immune system. However, when using primary cells in toxicology one needs to consider that access to them is often limited and variability in test results will be higher due to donor variability.

In addition, we included a few more complex models of the target organs such as 3D models and co-cultures. The use of complex cellular models has been discussed for some time as superior to the single layer dish culture (Guguen-Guillouzo et al. 1983). For their use in toxicology it is expected that such models could yield more relevant data requiring less modelling or extrapolation (Nam et al. 2015). Thereby, they are assumed to more reliably 
identifying a human hazard (Grainger 2014). As a more complex model we employed a commercially available reconstituted human epidermis ( $\mathrm{RHE}$ ) produced from a pool of human keratinocytes from different donors. These RHE are characterized by the presence of the 4 typical epidermis layers (basal, spinous, granular, and topical cornified layer) observed in in vivo epidermis and express specific differentiation markers such as keratin 14 , keratin 10 or involucrin (Poumay et al. 2004). RHE were treated at the air-liquid interface.

Furthermore, Caco-2 cells were differentiated on filters forming continuous polarized monolayers, and acquire several of the characteristics of normal enterocytes (Hillgren et al. 1995; Volpe 2008). Co-cultures of aforementioned A549 and NCl-H411 lung epithelial cells with THP-1 cells differentiated into macrophage-like cells were used to represent a situation more close to the lung surface (Hjort et al. 2003; Wottrich et al. 2004). All cell models employed in our study are listed in Supplemental Table 1. The selection of cell models was based on a literature survey, initial experiments, as well as on availability and experience in the participating laboratories. The aim of our study was to investigate the applicability of three cytotoxicity assays in a variety of different cell models representing the most important target organs for NPs. Amine-modified polystyrene NPs $\left(\mathrm{PS}-\mathrm{NH}_{2}\right)$ and carboxyl-modified polystyrene NPs (PS-COOH) were used as 'model' NPs as they exhibit narrow size ranges and low agglomeration (Bexiga et al. 2014; Kim et al. 2013; Wang et al. 2013). Moreover, the cationic PS- $\mathrm{NH}_{2}$ have been demonstrated to induce cytotoxicity at doses below $50 \mu \mathrm{g} / \mathrm{ml}$ (Anguissola et al. 2014; Bexiga et al. 2011; Ruenraroengsak et al. 2012; Wang et al. 2013; Xia et al. 2008). We have developed standard operation procedures (SOPs) and discussed some limitations and pitfalls. All SOPs are included in the Supplementary Information. 


\section{Material and methods}

\subsection{Chemicals and nanoparticles}

Benzalkonium chloride (BC, Sigma-Aldrich), known to induce cell death in multi-layered engineered tissues like RHE and in differentiated Caco-2 monolayers was used as positive control (Supplemental Table 2) (Coquette et al. 2003; Piret et al. 2012; Vankoningsloo et al. 2010). Zinc sulphate (Sigma-Aldrich) and Triton X-100 were used as positive chemical control for CD34-DCs or A549/THP-1 cells respectively (Supplemental Table 2).

Monodisperse aqueous dispersions of polystyrene (PS) NPs with amine (PS-NH $\mathrm{NH}_{2}$ and carboxyl (PS-COOH) surface functionalization (nominal size of $50 \mathrm{~nm}$ diameter) were obtained from Bangs Laboratories (catalog number PA02N) and Polysciences, Inc. (catalog number 15913-10), respectively. These NPs can be easily dispersed by simple vortexing as has been assured in an accompanying round robin using Dynamic Light Scattering (DLS) and Differential Centrifugal Sedimentation (DCS) (Langevin et al., under review). NPs were dispersed in cell culture media by vortexing for $30 \mathrm{sec}$ immediately prior to experiments. Particle size distributions in water and in cell culture medium with FCS were determined using Dynamic Light Scattering (Langevin et al., under review).

\subsection{Cell culture}

\subsubsection{A549 cell line}

Human lung epithelial A549 cells (obtained from LGC Standards, catalog number: ATCC ${ }^{\circledR}$ CRM-CCL-185 ${ }^{\mathrm{TM}}$ ) were cultured in RPMI 1640 medium (Gibco) supplemented with 10\% (v/v) heat-inactivated $\left(20 \mathrm{~min}, 56^{\circ} \mathrm{C}\right)$ fetal calf serum (FCS) (Sigma-Aldrich), $1 \%(\mathrm{v} / \mathrm{v})$ penicillinstreptomycin (Invitrogen). Cells were seeded at $10^{4}$ cells/well in 96 -well plates $42 \mathrm{~h}$ prior to exposure.

\subsection{2. $\mathrm{NCl}-\mathrm{H} 411$ cell line}

Human lung epithelial $\mathrm{NCl}-\mathrm{H} 411$ (catalog number: ATCC ${ }^{\circledR} \mathrm{HTB}-174^{\mathrm{TM}}$ ) cells obtained from LGC Standards were cultured in RPMI 1640 medium (Gibco) supplemented with $10 \%$ (v/v) 
heat-inactivated FCS (Sigma-Aldrich), 1\% (v/v) penicillin-streptomycin (Invitrogen). Cells were seeded at $10^{4}$ cells/well in 96-well plates $42 \mathrm{~h}$ prior to exposure.

\subsubsection{Naïve Caco-2 cell line and differentiated monolayers}

Human colon carcinoma Caco-2 cells were purchased from European Collection of Cell Cultures (ECACC, Salisbury, UK, catalog number: ECACC 86010202). Caco-2 cells were maintained in culture in $75-\mathrm{cm}^{2}$ polystyrene flasks (Costar) with DMEM High Glucose (Gibco) containing $100 \mathrm{U} / \mathrm{ml}$ penicillin, $100 \mu \mathrm{g} / \mathrm{ml}$ streptomycin (BioWhittaker), 1\% (v/v) non-essential amino-acids (Gibco) and 10\% FCS (Gibco).

To obtain a tight intestinal epithelium, Caco-2 cells were differentiated as described previously (Piret et al. 2012). Briefly, 50,000 Caco-2 cells were grown on transwell polycarbonate filters (12 wells, pore diameter of $3 \mu \mathrm{m}, 1.12 \mathrm{~cm}^{2}$ growth area, Corning Costar) for 16 days. Medium (500 $\mu \mathrm{L}$ in the insert -apical side-, and $1.5 \mathrm{~mL}$ in the well -basolateral side) was renewed every $48 \mathrm{~h}$. The tightness of the intestinal monolayers was controlled by transepithelial electrical resistance (TEER) measurement, performed with probes connected to a Millicell-ERS Volt-Ohm meter (Millipore). TEER data were calculated by subtracting the value of blank inserts and normalized for growth area $\left(\Omega . \mathrm{cm}^{2}\right)$. For toxicity assays, intestinal epithelia were incubated for $24 \mathrm{~h}$ with $500 \mu \mathrm{L}$ of complete DMEM containing increasing concentrations of PS- $\mathrm{NH}_{2}$.

\subsubsection{THP-1 cell line-derived macrophages and co-culture with lung epithelial cells} Human acute monocytic leukaemia THP-1 cells (obtained from LGC Standards, catalog number: ATCC ${ }^{\circledR}$ TIB-202 ${ }^{\mathrm{TM}}$ ) were cultured in RPMI 1640 medium (Gibco) supplemented with 10\% FCS (Sigma-Aldrich), 1\% L-glutamine, 1\% penicillin/streptomycin (Invitrogen), 1\% Hepes. THP-1 cells (non-adherent monocytic cells) were seeded at $8 \times 10^{4}$ cells/well in a 96well plates and differentiated in macrophage-like adherent cells according to the method previously described (Lanone et al. 2009) with $30 \mathrm{ng} / \mathrm{mL}$ of phorbol-12-myristate 13-acetate (Sigma-Aldrich) in RPMI medium $40 \mathrm{~h}$ prior to exposure. For co-culture, differentiated THP-1 cells were detached with $0.25 \%$ trypsin and seeded for $2 \mathrm{~h}$ on top of epithelial cells at a ratio of 1 macrophage for 2 epithelial cells on the day of exposure. 


\subsubsection{Normal human epidermal keratinocytes (NHEK)}

Neonatal NHEK (pool of three donors) were purchased from Lonza (catalog number: 192906). NHEK were grown in $75 \mathrm{~cm}^{2}$ flasks (Corning) to $80 \%$ confluence in presence of keratinocytes SFM medium supplemented with bovine pituitary extract and recombinant human epidermal growth factor (Gibco). Importantly, all steps were performed at $4^{\circ} \mathrm{C}$ when splitting NHEK in order to prevent differentiation.

\subsubsection{Reconstituted human epidermis (RHE)}

RHE (EPI/001) differentiated for 14 days and the related culture media were purchased from StratiCELL s.a. (Les Isnes, Belgium). RHE were produced from a pool of human keratinocytes from different donors seeded on a $0.63 \mathrm{~cm}^{2}$ polycarbonate filters and grown at the air-liquid interface. RHE were maintained in culture according to the manufacturer's recommendations.

\subsubsection{Primary CD34-derived dendritic cells (CD34-DCs)}

CD34 ${ }^{+}$-progenitor-cell isolation and culture procedures have been described previously (Nelissen et al. 2009). Briefly, human cord blood samples were collected from umbilical blood vessels of placentas of full-term infants, born at the Heilig Hart hospital in Mol and the St. Dimpna hospital in Geel, Belgium. Informed consent was given by the mothers and the study was approved by the ethical commission of both hospitals. Mononuclear cells were separated from the cord blood by density gradient centrifugation (Ficoll-Paque ${ }^{\mathrm{TM}}$ plus, GE Healthcare). Subsequently, CD34+ progenitor cells were extracted using positive immunomagnetic selection (EasySep $\AA$ human CD34 positive selection kit, Stemcell Technologies, Grenoble, France) according to the manufacturer's guidelines. The progenitor cells were cultured for 12 days in Iscove's Modified Dulbecco's Medium (IMDM, Gibco) supplemented with $10 \%$ fetal bovine serum (PAA laboratories, Pasching, Austria), $2 \%$ penicillin/streptomycin (Gibco) and 1\% bovine serum albumin (Sigma-Aldrich) in the presence of TNF- $\alpha$ (250 U/ml, Roche applied science), granulocyte macrophage colonystimulating factor (5000 U/ml; Gentaur, Brussels, Belgium), stem cell factor (5 U/ml, 
Biosource, Nivelles, Belgium) and interleukin 4 (1000 U/ml, Biosource) to induce proliferation and differentiation towards immature CD34-DCs.

All cell lines and complex in vitro models were maintained at $37^{\circ} \mathrm{C}$ in a $5 \% \mathrm{CO}_{2}$ incubator with humidified air.

\subsection{Cytotoxicity testing}

The detailed SOPs for MTS, LDH and ATP assays are included in supplemental files.. Cells were seeded as described above and treated with NPs in concentrations ranging from 1$100 \mu \mathrm{g} / \mathrm{ml}$, corresponding solvents or control chemicals, or left untreated for a period of $24 \mathrm{~h}$. Afterwards the different assays were applied. We have carefully checked for possible interferences for each of the assays, instructions are included in the SOPs.

\subsubsection{MTS assay}

For the MTS assay CellTiter $96^{\circledR}$ AQueous One Solution Reagent from Promega was used. After $24 \mathrm{~h}$ treatment with NPs, the medium was removed from each well and replaced by MTS solution, which has been prepared according to manufacturer instructions. The plate was then incubated at $37^{\circ} \mathrm{C}$ in a cell incubator for another $1 \mathrm{~h}$. The absorbance was read at $490 \mathrm{~nm}$. This SOP has been tested in an inter-laboratory comparison study (Nelissen et al, under review).

\subsubsection{LDH assay}

For the LDH assay, CytoTox-ONE ${ }^{\mathrm{TM}}$ Homogeneous Membrane Integrity Assay from Promega was used. After $24 \mathrm{~h}$ treatment, the medium was collected from each well and centrifuged at $15,700 \times g$ for 30 min to remove potentially interfering NPs and also cell debris. Afterwards $100 \mu$ cell supernatant was mixed with $100 \mu$ l CytoTox-ONE ${ }^{\mathrm{TM}}$ Reagent, incubated for $10 \mathrm{~min}$ at room temperature. Then, $50 \mu \mathrm{l}$ stop solution was added and fluorescence was recorded within one hour with an excitation wavelength between 530$570 \mathrm{~nm}$ and an emission wavelength between $580-620 \mathrm{~nm}$. 


\subsubsection{ATP assay}

For this purpose, ATPlite ${ }^{\mathrm{TM}}$ kit (PerkinElmer) was used according to the manufacturer's instructions. Additionally, total cellular protein content was assessed according to the Bradford method (BioRad) (Bradford 1976), and the ATP content normalized to it.

\subsection{Data analysis}

Half maximal effective doses ( $E D_{50}$ values) were determined by curve fitting performed in the R statistical computing environment (R Development Core Team, 2009) in combination with the drc package (Ritz and Streibig, 2005) using the five parametric logistic function. Mean $E D_{50}$ values were calculated from the averages of the logarithm of the $E D_{50}$ of independent biological experiments. Upper and lower bounds correspond to the standard deviation of the logarithmic mean. Student's $t$-test with a significance cut-off level $p$ of 0.05 was used to compare mean values of NP-treated with those of untreated cells. 


\section{Results}

In this study we evaluated the suitability of three different cytotoxicity assays for NP testing. We included six different single cell models and four complex cell models (Supplemental Table 1).

\subsection{Skin cell models}

For the skin models we used NHEK and RHE and applied three different assays (i.e. MTS, LDH and ATP assay). The quaternary ammonium compound and surfactant BC was used at $0.005 \mathrm{mg} / \mathrm{mL}$ (NHEK, MTS and LDH assays; $0.0025^{\circ} \mathrm{mg} / \mathrm{mL}$ ATP assay) or $1 \mathrm{mg} / \mathrm{mL}$ (RHE) as a positive control and quality control to verify the performance of the assays (Supplemental Table 2).

In NHEK cells, we detected a clear dose dependent effect of PS-NH $\mathrm{NH}_{2}$ on cell viability using the ATP and MTS assays (Figure $1 A$ and $B$ ), with $E D_{50}$ values of $37 \mu \mathrm{g} / \mathrm{mL}$ and $25 \mu \mathrm{g} / \mathrm{mL}$, respectively (Table 1). For PS-COOH we could not observe any effect for all the tested concentrations. Please note, that although the manufacturer of the ATP assay recommended the normalization of the results using the sample's protein content, in our experience normalization introduced high variation in the results as seen for NHEK (Supplemental Figure 1A). Therefore, and because plated cell numbers were tightly controlled in the experiments, the ATP assay results are reported without such normalization. However, reduced ATP levels and reduced cell numbers cannot be distinguished in our results. The LDH assay proved to be less sensitive and a cytotoxic effect was only detected for $\mathrm{PS}-\mathrm{NH}_{2}$ at a dose of $100 \mu \mathrm{g} / \mathrm{mL}$ (Figure 1C).

In parallel, in vitro $\mathrm{RHE}$ were treated with $\mathrm{PS}-\mathrm{NH}_{2}$ or $\mathrm{BC}$ at the air-liquid interface. As the use of RHE was cost intense and all previous tests using PS-COOH on NHEK did not show an effect on viability, only PS- $\mathrm{NH}_{2}$ at a dose of $31.25 \mu \mathrm{g} / \mathrm{cm}^{2}$ (equivalent to $100 \mu \mathrm{g} / \mathrm{mL}$ inducing the highest toxic effect on NHEK, Figure 1) was tested. NPs were added topically as a liquid dispersion on the cornified layer and incubated for 24 h. Phosphate Buffered Saline (PBS) solution was used to evaluate the potential effect of a buffered liquid on RHE viability. No toxic effect of PS- $\mathrm{NH}_{2}$ on epidermises was detected using either the MTS or LDH assay 
(Figure 2), while the positive control BC caused a dramatic loss of epidermis viability measured with both assays (Supplemental Table 2).

\subsection{Lung cell models}

As a model for lung exposure we used two lung related cells lines (A549 cells or $\mathrm{NCl}-\mathrm{H} 411$ cells) in monoculture as well as in co-culture with THP-1-differentiated macrophages. Triton $\mathrm{X}-100$ was used as a positive control in the lung cell experiments (Supplemental Table 2). The lung cells models alone (i.e. A549 or $\mathrm{NCl}-\mathrm{H} 441$ cells) reached $\mathrm{ED}_{50}$ values of $117 \mu \mathrm{g} / \mathrm{mL}$ and $77 \mu \mathrm{g} / \mathrm{mL}$ in the MTS assay, respectively (Figure 3, Supplemental Figure 2, and Table 1). In contrast, monocultures of THP-1 cells were observed to be more sensitive with an $E D_{50}$ of $54 \mu \mathrm{g} / \mathrm{mL}$ in the MTS assay (Table 1). Co-cultures showed similar effects compared to the lung cell models (i.e. A549 and $\mathrm{NCl}-\mathrm{H} 441$ ) alone with $\mathrm{ED}_{50}$ values of $112 \mu \mathrm{g} / \mathrm{mL}$ and $64 \mu \mathrm{g} / \mathrm{mL}$ in the MTS assay, respectively (Table 1). Similar results were derived in the ATP and the LDH assays (Figure 3, Supplemental Figure 2, and Table 1). In all assays THP-1 cells alone were the most sensitive cells. In addition, PS-COOH were tested in the three assays and the five airway cell models, and no cytotoxicity was detected (Figure 3, Supplemental Figure 2).

\subsection{Intestinal cell models}

The response of Caco-2 cells to NPs was tested using undifferentiated and differentiated cells as intestinal model, representing oral intake. BC was used at as positive control (Piret et al. 2012) to verify the performance of the assays (Supplemental Table 2). In addition, TEER was measured on differentiated Caco-2 cells to evaluate the effect of NPs on the intestinal epithelium integrity.

Undifferentiated Caco-2 cells exhibited a dose dependent loss of viability after $\mathrm{PS}-\mathrm{NH}_{2}$ exposure with an $\mathrm{ED}_{50}$ of $73 \mu \mathrm{g} / \mathrm{mL}$ in the MTS assay and a somewhat higher $\mathrm{ED}_{50}$ of $103 \mu \mathrm{g} / \mathrm{mL}$ in the ATP assay (Figure 4A and B, Table 1). PS-COOH did not show any cytotoxicity in both assays (Figure 4A and B). Using the LDH assay, low levels of fluorescence signals and high background were encountered with this cell line. 
Recommended changes to the protocol to overcome these issues such as reduction of serum (that may contain LDH) to reduce high background and the use of pyruvate-free medium together with an increase of incubation time and temperature to reduce low overall fluorescence signals were unsuccessful. Therefore, no LDH assay results were obtained for this cell line.

The impact of PS- $\mathrm{NH}_{2}$ on viability and integrity of intestinal Caco-2 monolayers obtained after differentiation was evaluated by the MTS assay and measurement of the TEER, respectively. In order to respect the same NP doses $/ \mathrm{cm}^{2}$ used with undifferentiated Caco-2 cells during viability assays (using 96-well plates), intestinal monolayers (using transwells) were exposed to PS- $\mathrm{NH}_{2}$ concentrations between $70 \mu \mathrm{g} / \mathrm{mL}$ (i.e. $100 \mu \mathrm{g} / \mathrm{mL}$ on undifferentiated Caco-2 cells, corresponding to $31.25 \mu \mathrm{g} / \mathrm{cm}^{2}$ in both the cases) and $0.7 \mu \mathrm{g} / \mathrm{mL}$ (i.e. $1 \mu \mathrm{g} / \mathrm{mL}$ on undifferentiated Caco-2 cells, corresponding to $3.125 \mu \mathrm{g} / \mathrm{cm}^{2}$ in both the cases). No effect on intestinal epithelium viability and integrity was observed with $\mathrm{PS}-\mathrm{NH}_{2}$ independently of the concentration (Figure 4B and C, respectively), while BC reduced viability to $20 \%$ and caused complete breakdown of the electrical resistance (Supplemental Table 2). PS-COOH were not tested since no effect was seen on naïve Caco-2 cells (Figure 4A and B).

\subsection{Immune cell models}

In addition to the THP-1 cells discussed earlier (Figure 3, Supplemental Figure 2), CD34DCs prepared from different human cord blood donors were investigated as models of the immune system. As expected, donor variability had a strong impact on the quality of the assay results. However, similar trends to THP-1 cells were observed as $\mathrm{PS}-\mathrm{NH}_{2}$ induced cytotoxicity at low doses for some donors (Figure 5). Zinc sulphate (144 nM) was used as a positive control showing less than $20 \%$ cell viability or of ATP content compared to untreated controls cells in all donors (Supplemental Table 2).

The average $\mathrm{ED}_{50}$ for PS-NH $\mathrm{H}_{2}$ in the ATP assay was $26 \mu \mathrm{g} / \mathrm{mL}$ (Figure $5 \mathrm{~A}$ and Table 1 ), and for the MTS assay the $\mathrm{ED}_{50}$ was $82 \mu \mathrm{g} / \mathrm{ml}$ (Figure 5B and Table 1). LDH release was observed only at doses of $100 \mu \mathrm{g} / \mathrm{mL}$ (Figure 5C and Table 1), which was not significant. In all cases, PS-COOH did not display any cytotoxic effect to the cells (Figure 5). 


\section{Discussion}

We compared three cytotoxicity assays (MTS, ATP, and LDH assays) that cover different biological principles (redox metabolism, ATP content, membrane permeability) and different read-out principles (absorption, fluorescence and luminescence) on different cell models (Supplemental Table 1). The cell models covered the main routes of exposure to NPs (cutaneous exposure, ingestion, inhalation, and i.v. injection) and therefore represented the most important target organs. PS- $\mathrm{NH}_{2}$ and PS-COOH were used as an example of ideal NPs as they were available with a perfect spherical shape with a very narrow size distribution and were easy to disperse by vortexing yielding stable dispersions. Moreover, previous studies already suggested that PS- $\mathrm{NH}_{2}$ induce cytotoxicity and PS-COOH are of low or no cytotoxicity (Anguissola et al. 2014; Bexiga et al. 2011; Ruenraroengsak et al. 2012; Wang et al. 2013; Xia et al. 2008). Indeed, in this study all assays showed that PS-COOH had no effect on the cell viability within the tested dose range up to $100 \mu \mathrm{g} / \mathrm{mL}$ in none of the cell models. In contrast, $\mathrm{PS}-\mathrm{NH}_{2}$ induced a dose-dependent cytotoxicity in most cell models tested in all assays. We thoroughly tested for possible interference of the NPs in all the test assays and we could confirm absence of interferences. Therefore, our data confirm that PS$\mathrm{COOH}$ and PS-NH $\mathrm{N}_{2}$ are very good candidates for negative and positive control nanomaterials, respectively, for in vitro cytotoxicity measurements.

The ATP assay was the most sensitive assay, yielding the lowest $E D_{50}$ values in most cell models. However, $\mathrm{ED}_{50}$ values of the MTS assay were often in the same range as those of the ATP assay. This might be related to the fact that ATP results were not normalized by the protein content. Importantly, for a conclusion on general cytotoxicity such a conflation is unproblematic provided that cells were not significantly proliferating during the treatment period. Therefore, the MTS and the ATP assays both appear suitable for cytotoxicity testing of NPs as previously described (Piret et al. 2017). While the LDH assay also indicated cytotoxicity in most cell models it proved to be the least sensitive assay. Often $\mathrm{ED}_{50}$ values were not reached within the tested dose range. These results are in line with the biological basis of the methods which suggests ATP levels to be affected earliest, NAD(P)H 
oxidoreductases somewhat later and loss of membrane integrity as a late effect. However, some issues of high background and low overall levels of fluorescence signals in the LDH assay were encountered with certain cell models, i.e. Caco-2 cells and CD34-derived dendritic cells. These render this assay not recommendable for those cell models. The two tissue models involving monocultures of differentiated cells, i.e. reconstituted epidermis and differentiated (intestinal) Caco-2 cell monolayer were unaffected by $\mathrm{PS}-\mathrm{NH}_{2}$ in the tested dose range regardless of the type of viability assay. This was in contrast to the results obtained in the respective cell models that were used to grow these more complex models, i.e. NHEK and Caco-2 cells. In vitro reconstituted human epidermises exhibit the barrier function of cornified cells, emphasizing the excluding/protective role of the upper layer of the epidermis in case of acute exposure to PS- $\mathrm{NH}_{2}$ The susceptibility of NHEK cells indicated a potential toxic effect in case of a breach of the barrier function. In the case of differentiated Caco-2 cells (Jumarie and Malo 1991), the change of cellular features such as cell polarity, microvilli formation, tight junctions, domes and increased brush-border membrane enzymatic activities, and the secretion and assembly of an extracellular matrix because of the long undisturbed culture period might be responsible for protecting them from the cytotoxic effect of PS-NH $\mathrm{NH}_{2}$ that was observed in the undifferentiated counterparts. In addition, the integrity of the intestinal epithelia generated by the Caco-2 differentiation was not affected by the NPs as confirmed by TEER measurements. All together, these data underline the importance of considering more complex cell models in the evaluation of NP toxicity as differences were observed depending on the differentiation status and complexity of cell models.

Cells of the immune system are expected to be among the first cells to encounter NPs after they breach barriers and become systemically available. Here we tested two types of models for immune cells, phorbol ester-primed THP-1 monocytes and CD34-DCs. Both cell types showed a higher sensitivity towards PS- $\mathrm{NH}_{2}$ compared to the epithelial cell types. However, in a co-culture of THP-1 cells with lung cells the co-cultures exhibited $\mathrm{ED}_{50}$ values more comparable to the lung epithelial cells alone, arguing that within the incubation time the effect 
of the immune cells is rather low (Loret et al. 2016). However, immune cells, especially macrophages, can elicit a so-called respiratory burst during which they release reactive oxygen species and cytokines into the surrounding tissue (Forman and Torres 2002). The respiratory burst has been observed in response to NP treatment (Cruz et al. 1997; Prietl et al. 2014). Prolonged exposure and hence release of reactive oxygen species and cytokines can lead to inflammation. Upon chronic stimulation this might lead to tissue scarring and reduced organ function and possibly tumorigenesis (Babior 2000). This argues, that macrophages should always be included when testing NPs because of the necessity to record possible respiratory burst reactions at least for lung epithelial models.

Table 2 summarizes the findings of this study with respect to the different cell models. Overall, we achieved to develop robust SOPs for all three assays, i.e. MTS, ATP and LDH assays, which have been tested for a variety of important cell models. However, several possible improvements of these SOPs can be considered in future. Improvements could concern the exposure of the NPs, such as pre-incubation of the NPs with a more realistic biofluid prior to cell treatments. For instance, surfactant can be used in the case of lung models (McKenzie et al. 2015; Raesch et al. 2015) and for oral uptake the different consecutive $\mathrm{pH}$ values encountered along the stages of the gastro-intestinal tract can be simulated (Peters et al. 2012). Furthermore, skin and lung models may be exposed at the airliquid interface (Stoehr et al. 2015) while ingestion models could include a more realistic digestion fluid on one side. Finally, cell models are being refined, and new developments such as microfluidic systems and organoids promise to allow more realistic models and to eliminate the species differences in toxicological data by using human cells (Esch et al. 2014; Tralau et al. 2015).

\section{Conclusions}

All assays investigated here should be applicable for all NPs when known issues of interference and artefacts have been controlled for (Bonvin et al. 2017; Kroll et al. 2012; Monteiro-Riviere et al. 2009; Stone et al. 2009; Tournebize et al. 2013). In summary, the MTS assay was applicable for all tested cell models, including primary cells and more 
complex models and therefore represents the most robust and reproducible assay out of the three tested assays. Thus, our data confirm previous findings that the MTS assay should be integrated in an in vitro NP test strategy (Piret et al. 2017). However, other assays can be useful as well, depending on the NP type and the cell model. The ATP assay proved to be more sensitive in several cell models investigated here and thus could be useful in a test strategy too, provided that the issues with normalization can be overcome. Our data also show that combining different assays, which represent different biological read-out gives a more complete picture especially on the chronological sequence of different events and allows already first conclusions on possible underlying mechanisms of cytotoxicity. Furthermore, our data suggest that PS-COOH and PS- $\mathrm{NH}_{2}$ may be used as negative and positive control NPs, respectively, for NP cytotoxicity testing.

\section{Acknowledgements}

We are grateful to the excellent technical assistance of Kelly Blazy and Christelle Gamez (INERIS, France) as well as of An Jacobs (VITO, Belgium).

\section{Funding}

We would like to acknowledge funding from the EC FP7 project QualityNano (INFRA-20101.1.31-262163). J.-P. Piret and O. Toussaint would like to thank the DG06 (Direction générale opérationnelle de l'Economie, de l'Emploi \& de la Recherche) of the Walloon Region of Belgium for the project Complement 'QNano' (2011-14) n`1117448. O. Toussaint unfortunately deceased in 2016 and was a senior Research Associate from the Belgian F.R.S.-FNRS. In addition, the authors are grateful to all institutions for supporting this work.

\section{Declaration of Interest}

The authors declare no competing interests. 


\section{List of abbreviations}

BC: $\quad$ benzalkonium chloride

CD34-DCs: CD34-derived dendritic cells

FCS: $\quad$ fetal calf serum

HTS: $\quad$ high-throughput screening

HCS: $\quad$ high-content screening

ISO: International Organization for Standardization

LDH: $\quad$ lactate dehydrogenase

MTS: $\quad$ 3-(4,5-dimethylthiazol-2-yl)-5-(3-carboxymethoxyphenyl)-2-(4-sulfophenyl)-2Htetrazolium

MTT: $\quad$ 3-(4,5-dimethylthiazol-2-yl)-2,5-diphenyltetrazolium bromide

NP: $\quad$ nanoparticle

NHEK: normal human epidermal keratinocytes

PS-COOH $\quad 40 \mathrm{~nm}$ carboxyl-modified polystyrene nanoparticles

PS-NH $\mathrm{N}_{2} \quad 50 \mathrm{~nm}$ amine-modified polystyrene nanoparticles

$\mathrm{RHE} \quad$ reconstituted human epidermis

SOP standard operation procedure

TEER transepithelial electrical resistance 


\section{References}

Aki T, Funakoshi T, Uemura K (2015) Regulated necrosis and its implications in toxicology. Toxicology 333:118-126 doi:10.1016/j.tox.2015.04.003

Anguissola S, Garry D, Salvati A, O'Brien PJ, Dawson KA (2014) High content analysis provides mechanistic insights on the pathways of toxicity induced by amine-modified polystyrene nanoparticles. PLoS One 9(9):e108025 doi:10.1371/journal.pone.0108025

Babior BM (2000) Phagocytes and oxidative stress. Am J Med 109(1):33-44 doi:10.1016/S0002-9343(00)00481-2

Balasubramanian SK, Poh KW, Ong CN, Kreyling WG, Ong WY, Yu LE (2013) The effect of primary particle size on biodistribution of inhaled gold nano-agglomerates. Biomaterials 34(22):5439-5452 doi:10.1016/j.biomaterials.2013.03.080

Bexiga MG, Kelly C, Dawson KA, Simpson JC (2014) RNAi-mediated inhibition of apoptosis fails to prevent cationic nanoparticle-induced cell death in cultured cells. Nanomedicine (Lond) 9(11):1651-1664 doi:10.2217/nnm.13.151

Bexiga MG, Varela JA, Wang F, et al. (2011) Cationic nanoparticles induce caspase 3-, 7and 9-mediated cytotoxicity in a human astrocytoma cell line. Nanotoxicol 5(4):557567 doi:10.3109/17435390.2010.539713

Bonvin D, Hofmann H, Mionic Ebersold M (2017) Assessment of nanoparticles' safety: corrected absorbance-based toxicity test. Analyst 142(13):2338-2342 doi:10.1039/c7an00382j

Bradford MM (1976) A rapid and sensitive method for the quantitation of microgram quantities of protein utilizing the principle of protein-dye binding. Anal Biochem 72:248-54

Chanput W, Mes JJ, Wichers HJ (2014) THP-1 cell line: an in vitro cell model for immune modulation approach. Int Immunopharmacol 23(1):37-45 doi:10.1016/j.intimp.2014.08.002

Coquette A, Berna N, Vandenbosch A, Rosdy M, De Wever B, Poumay Y (2003) Analysis of interleukin-1alpha (IL-1alpha) and interleukin-8 (IL-8) expression and release in in vitro reconstructed human epidermis for the prediction of in vivo skin irritation and/or sensitization. Toxicol In Vitro 17(3):311-21

Cruz T, Gaspar R, Donato A, Lopes C (1997) Interaction between polyalkylcyanoacrylate nanoparticles and peritoneal macrophages: MTT metabolism, NBT reduction, and NO production. Pharm Res 14(1):73-79 doi:10.1023/A:1012059501947

Elliott JT, Rosslein M, Song NW, et al. (2017) Toward achieving harmonization in a nanocytotoxicity assay measurement through an interlaboratory comparison study. ALTEX 34(2):201-218 doi:10.14573/altex.1605021

Esch MB, Mahler GJ, Stokol T, Shuler ML (2014) Body-on-a-chip simulation with gastrointestinal tract and liver tissues suggests that ingested nanoparticles have the potential to cause liver injury. Lab Chip 14(16):3081-3092 doi:10.1039/c4lc00371c

Forman HJ, Torres M (2002) Reactive oxygen species and cell signaling: respiratory burst in macrophage signaling. Am J Respir Crit Care Med 166(12 Pt 2):S4-8 doi:10.1164/rccm.2206007

Foster KA, Oster CG, Mayer MM, Avery ML, Audus KL (1998) Characterization of the A549 cell line as a type II pulmonary epithelial cell model for drug metabolism. Exp Cell Res 243(2):359-366 doi:10.1006/excr.1998.4172

Galluzzi L, Kepp O, Krautwald S, Kroemer G, Linkermann A (2014) Molecular mechanisms of regulated necrosis. Semin Cell Dev Biol 35:24-32 doi:10.1016/j.semcdb.2014.02.006

Grainger DW (2014) Cell-based drug testing; this world is not flat. Adv Drug Deliv Rev 6970:vii-xi doi:10.1016/j.addr.2014.04.001

Green DR, Galluzzi L, Kroemer G (2014) Cell biology. Metabolic control of cell death. Science 345(6203):1250256 doi:10.1126/science.1250256 
Guguen-Guillouzo C, Clement B, Baffet G, et al. (1983) Maintenance and reversibility of active albumin secretion by adult rat hepatocytes co-cultured with another liver epithelial cell type. Exp Cell Res 143(1):47-54

Hartung T (2008) Towards a new toxicology - evolution or revolution? Altern. Lab. Anim. 36: 635-639

Hermanns MI, Unger RE, Kehe K, Peters K, Kirkpatrick CJ (2004) Lung epithelial cell lines in coculture with human pulmonary microvascular endothelial cells: development of an alveolo-capillary barrier in vitro. Lab Invest 84(6):736-752 doi:10.1038/labinvest.3700081

Hillgren KM, Kato A, Borchardt RT (1995) In vitro systems for studying intestinal drug absorption. Med Res Rev 15(2):83-109 doi:10.1002/med.2610150202

Hjort MR, Brenyo AJ, Finkelstein JN, et al. (2003) Alveolar epithelial cell-macrophage interactions affect oxygen-stimulated interleukin-8 release. Inflammation 27(3):137145 doi:10.1023/A:1023817811850

Judson R, Kavlock R, Martin M, Reif D, Houck K, Knudsen T, Richard A, Tice RR, Whelan M, Xia M, Huang R, Austin C, Daston G, Hartung T, Fowle JR, Wooge W, Tong T, Dix D (2013) Perspectives on Validation of High-Throughput Assays Supporting 21st Century Toxicity Testing. ALTEX. 30: 51-56

Jumarie C, Malo C (1991) Caco-2 cells cultured in serum-free medium as a model for the study of enterocytic differentiation in vitro. J Cell Physiol 149(1):24-33 doi:10.1002/jcp.1041490105

Kangas L, Gronroos M, Nieminen AL (1984) Bioluminescence of cellular ATP: a new method for evaluating cytotoxic agents in vitro. Med Biol 62(6):338-343

Kendall M, Holgate S (2012) Health impact and toxicological effects of nanomaterials in the lung. Respirology 17(5):743-758 doi:10.1111/j.1440-1843.2012.02171.x

Kim JA, Aberg C, de Carcer G, Malumbres M, Salvati A, Dawson KA (2013) Low dose of amino-modified nanoparticles induces cell cycle arrest. ACS nano 7(9):7483-7494 doi:10.1021/nn403126e

Korzeniewski C, Callewaert DM (1983) An enzyme-release assay for natural cytotoxicity. J Immunol Methods 64(3):313-320 doi:10.1016/0022-1759(83)90438-6

Kreyling WG, Hirn S, Möller W, et al. (2014) Air-blood barrier translocation of tracheally instilled gold nanoparticles inversely depends on particle size. ACS nano 8(1):222233 doi:10.1021/nn403256v

Kroll A, Pillukat MH, Hahn D, Schnekenburger J (2012) Interference of engineered nanoparticles with in vitro toxicity assays. Arch Toxicol 86(7):1123-1136 doi:10.1007/s00204-012-0837-z

Labouta HI, Schneider M (2013) Interaction of inorganic nanoparticles with the skin barrier: current status and critical review. Nanomedicine 9(1):39-54 doi:10.1016/j.nano.2012.04.004

Lanone S, Rogerieux F, Geys J, et al. (2009) Comparative toxicity of 24 manufactured nanoparticles in human alveolar epithelial and macrophage cell lines. Part Fibre Toxicol 6:14 doi:10.1186/1743-8977-6-14

Lewinson J, Mayr W, Wagner H (1994) Characterization and toxicological behavior of synthetic amorphous hydrophobic silica. Regul Toxicol Pharmacol 20(1 Pt 1):37-57 doi:S0273-2300(84)71035-X [pii];10.1006/rtph.1994.1035 [doi]

Loret T, Peyret E, Dubreuil M, et al. (2016) Air-liquid interface exposure to aerosols of poorly soluble nanomaterials induces different biological activation levels compared to exposure to suspensions. Part Fibre Toxicol 13(1):58 doi:10.1186/s12989-016-01713

Martin KR (2007) The chemistry of silica and its potential health benefits. J Nutr Health Aging 11(2):94-97

McKenzie Z, Kendall M, Mackay RM, et al. (2015) Surfactant protein A (SP-A) inhibits agglomeration and macrophage uptake of toxic amine modified nanoparticles. Nanotoxicology 9(8):952-962 doi:10.3109/17435390.2014.992487 
Monteiro-Riviere NA, Inman AO, Zhang LW (2009) Limitations and relative utility of screening assays to assess engineered nanoparticle toxicity in a human cell line. Toxicol Appl Pharmacol 234(2):222-235 doi:10.1016/j.taap.2008.09.030

Mosmann T (1983) Rapid colorimetric assay for cellular growth and survival: application to proliferation and cytotoxicity assays. J Immunol Methods 65(1-2):55-63 doi:10.1016/0022-1759(83)90303-4

Nam K-H, Smith AST, Lone S, Kwon S, Kim DH (2015) Biomimetic three-dimensional tissue models for advanced high-throughput drug screening. J Lab Autom. 20: 201-215

Nelissen I, Selderslaghs I, Heuvel RV, Witters H, Verheyen GR, Schoeters G (2009) MUTZ3-derived dendritic cells as an in vitro alternative model to CD34+ progenitor-derived dendritic cells for testing of chemical sensitizers. Toxicol In Vitro 23(8):1477-1481 doi:10.1016/j.tiv.2009.08.022

Nohynek GJ, Dufour EK (2012) Nano-sized cosmetic formulations or solid nanoparticles in sunscreens: a risk to human health? Arch Toxicol 86(7):1063-1075 doi:10.1007/s00204-012-0831-5 [doi]

Peters R, Kramer E, Oomen AG, et al. (2012) Presence of nano-sized silica during in vitro digestion of foods containing silica as a food additive. ACS nano 6(3):2441-2451 doi:10.1021/nn204728k

Petronilli V, Penzo D, Scorrano L, Bernardi P, Di Lisa F (2001) The mitochondrial permeability transition, release of cytochrome $\mathrm{c}$ and cell death. Correlation with the duration of pore openings in situ. J Biol Chem 276(15):12030-12034 doi:10.1074/jbc.M010604200

Piret JP, Bondarenko OM, Boyles MSP, et al. (2017) Pan-European inter-laboratory studies on a panel of in vitro cytotoxicity and pro-inflammation assays for nanoparticles. Arch Toxicol 91(6):2315-2330 doi:10.1007/s00204-016-1897-2

Piret JP, Mejia J, Lucas S, Zouboulis CC, Saout C, Toussaint O (2014) Sonicated and stirred copper oxide nanoparticles induce similar toxicity and pro-inflammatory response in $\mathrm{N}$-hTERT keratinocytes and SZ95 sebocytes. J Nanopart Res 16(4) doi:10.1007/s11051-014-2337-y

Piret JP, Vankoningsloo S, Mejia J, et al. (2012) Differential toxicity of copper (II) oxide nanoparticles of similar hydrodynamic diameter on human differentiated intestinal Caco-2 cell monolayers is correlated in part to copper release and shape. Nanotoxicology 6(7):789-803 doi:10.3109/17435390.2011.625127

Poumay Y, Dupont F, Marcoux S, Leclercq-Smekens M, Herin M, Coquette A (2004) A simple reconstructed human epidermis: preparation of the culture model and utilization in in vitro studies. Arch Dermatol Res 296(5):203-11 doi:10.1007/s00403004-0507-y

Prietl B, Meindl C, Roblegg E, Pieber TR, Lanzer G, Frohlich E (2014) Nano-sized and micro-sized polystyrene particles affect phagocyte function. Cell Biol Toxicol 30(1):116 doi:10.1007/s10565-013-9265-y

Raesch SS, Tenzer S, Storck W, et al. (2015) Proteomic and Lipidomic Analysis of Nanoparticle Corona upon Contact with Lung Surfactant Reveals Differences in Protein, but Not Lipid Composition. ACS nano:in press doi:10.1021/acsnano.5b04215

Rösslein M, Elliott JT, Salit M, et al. (2015) Use of Cause-and-Effect Analysis to Design a High-Quality Nanocytotoxicology Assay. Chem Res Toxicol 28(1):21-30 doi:10.1021/tx500327y

Ruenraroengsak P, Novak P, Berhanu D, et al. (2012) Respiratory epithelial cytotoxicity and membrane damage (holes) caused by amine-modified nanoparticles. Nanotoxicol 6(1):94-108 doi:10.3109/17435390.2011.558643

Salomon JJ, Muchitsch VE, Gausterer JC, et al. (2014) The cell line NCl-H441 is a useful in vitro model for transport studies of human distal lung epithelial barrier. Mol Pharm 11(3):995-1006 doi:10.1021/mp4006535

Skocaj M, Filipic M, Petkovic J, Novak S (2011) Titanium dioxide in our everyday life; is it safe? Radiol Oncol 45(4):227-247 doi:10.2478/v10019-011-0037-0 
Stepanenko AA, Dmitrenko VV (2015) Pitfalls of the MTT assay: Direct and off-target effects of inhibitors can result in over/underestimation of cell viability. Gene 574(2):193-203 doi:10.1016/j.gene.2015.08.009

Stoehr LC, Endes C, Radauer-Preiml I, et al. (2015) Assessment of a panel of interleukin-8 reporter lung epithelial cell lines to monitor the pro-inflammatory response following zinc oxide nanoparticle exposure under different cell culture conditions. Part Fibre Toxicol 12:29 doi:10.1186/s12989-015-0104-6

Stone V, Johnston H, Schins RP (2009) Development of in vitro systems for nanotoxicology: methodological considerations. Crit Rev Toxicol 39(7):613-626 doi:10.1080/10408440903120975

Tournebize J, Sapin-Minet A, Bartosz G, Leroy P, Boudier A (2013) Pitfalls of assays devoted to evaluation of oxidative stress induced by inorganic nanoparticles. Talanta 116:753-763 doi:10.1016/j.talanta.2013.07.077

Tralau T, Oelgeschlager M, Gurtler R, et al. (2015) Regulatory toxicology in the twenty-first century: challenges, perspectives and possible solutions. Arch Toxicol 89(6):823-850 doi:10.1007/s00204-015-1510-0

Vankoningsloo S, Piret JP, Saout C, et al. (2010) Cytotoxicity of multi-walled carbon nanotubes in three skin cellular models: effects of sonication, dispersive agents and corneous layer of reconstructed epidermis. Nanotoxicology 4(1):84-97 doi:10.3109/17435390903428869

Volpe DA (2008) Variability in Caco-2 and MDCK cell-based intestinal permeability assays. J Pharm Sci 97(2):712-725 doi:10.1002/jps.21010

Wang F, Yu L, Monopoli MP, et al. (2013) The biomolecular corona is retained during nanoparticle uptake and protects the cells from the damage induced by cationic nanoparticles until degraded in the lysosomes. Nanomedicine 9(8):1159-1168 doi:10.1016/j.nano.2013.04.010

Weir A, Westerhoff P, Fabricius L, Hristovski K, von Goetz N (2012) Titanium dioxide nanoparticles in food and personal care products. Environ Sci Technol 46(4):22422250 doi:10.1021/es204168d [doi]

Wottrich R, Diabate S, Krug HF (2004) Biological effects of ultrafine model particles in human macrophages and epithelial cells in mono- and co-culture. Int J Hyg Environ Health 207(4):353-361 doi:10.1078/1438-4639-00300

Xia T, Hamilton RF, Bonner JC, et al. (2013) Interlaboratory evaluation of in vitro cytotoxicity and inflammatory responses to engineered nanomaterials: the NIEHS Nano GO Consortium. Environ Health Perspect 121(6):683-690 doi:10.1289/ehp.1306561

Xia T, Kovochich M, Liong M, Zink JI, Nel AE (2008) Cationic polystyrene nanosphere toxicity depends on cell-specific endocytic and mitochondrial injury pathways. ACS nano 2(1):85-96 doi:10.1021/nn700256c 


\section{Tables}

Table 1: Cytotoxicity of PS- $\mathrm{NH}_{2}$ in different cell models. Average $\mathrm{ED}_{50}$ values and lower and upper bounds in $\mu \mathrm{g} / \mathrm{mL}$.

\begin{tabular}{llllllllll}
\hline & ATP & & & MTS & & LDH & \\
& avg & lower & upper & avg & lower & upper & avg & lower & upper \\
\hline NHEK & 37 & 27 & 52 & 25 & 23 & 28 & & & \\
A549 & 40 & 22 & 71 & 117 & 92 & 149 & 155 & 143 & 167 \\
A549 + & 47 & 24 & 90 & 112 & 95 & 133 & 191 & 165 & 220 \\
THP-1 & & & & & & & & & \\
NCl-H411 & 65 & 58 & 71 & 77 & 73 & 81 & 104 & 96 & 113 \\
NCI-H411 + & 52 & 46 & 59 & 64 & 58 & 71 & 120 & 94 & 153 \\
THP-1 & & & & & & & & & \\
Caco-2 & 103 & 101 & 106 & 73 & 62 & 85 & & & \\
CD34-DCs & 26 & 13 & 53 & 82 & 38 & 174 & & & \\
THP-1 & 23 & 12 & 42 & 54 & 43 & 68 & 96 & 41 & 218 \\
\hline
\end{tabular}

Table 2: Cytotoxicity of PS-COOH and PS- $\mathrm{NH}_{2}$ in the different cell models. Negative: no cytotoxicity observed up to $100 \mu \mathrm{g} / \mathrm{mL}$; positive: average $\mathrm{ED}_{50}$ determined (see Table 1), n.d.: not determined.

\begin{tabular}{lllllll}
\hline & PS-COOH & & PS-NH & & \\
& ATP & MTS & LDH & ATP & MTS & LDH \\
\hline NHEK & negative & negative & negative & positive & positive & positive \\
RHE & n.d. & n.d. & n.d. & n.d. & negative & negative \\
A549 & negative & negative & negative & positive & positive & positive \\
A549 + THP-1 & negative & negative & negative & positive & positive & positive \\
NCI-H411 & negative & negative & negative & positive & positive & positive \\
NCl-H411+ THP-1 & negative & negative & negative & positive & positive & positive \\
Caco-2 & negative & negative & n.d. & positive & positive & n.d. \\
Differentiated Caco-2 & n.d. & n.d. & n.d. & n.d. & negative & n.d. \\
CD34-DCs & negative & negative & negative & positive & positive & n.d. \\
THP-1 & negative & negative & negative & positive & positive & positive \\
\hline
\end{tabular}




\section{Figure legends}

\section{Figure 1}

Cytotoxicity of surface-modified polystyrene nanoparticles in normal human epidermal keratinocytes.

Cells were exposed to increasing concentrations $(0,1,10,25,50$ and $100 \mu \mathrm{g} / \mathrm{ml})$ of PS$\mathrm{COOH}$ (filled symbols) or PS-NH $\mathrm{NH}_{2}$ (open symbols) for $24 \mathrm{~h}$. Effects on cells were assessed using the (A) ATP assay, (B) MTS assay, and (C) LDH release assay. Results were expressed as percentages (ATP -A- and MTS -B- assays) or as fold induction levels of control cells (LDH assay). For the ATP assay and the LDH release assay, 2 independent experiments were performed each (diamonds and triangles, respectively); individual data points are shown. The MTS assay was performed in 3 independent experiments; mean values with standard deviation are shown (circles). Curves are regressions over mean values.

\section{Figure 2}

Cytotoxicity of amine-modified polystyrene nanoparticles in reconstituted human epidermis (RHE).

RHE were incubated for $24 \mathrm{~h}$ with an equivalent volume of vehicle (phosphate buffered saline, PBS), $1 \mathrm{mg} / \mathrm{ml}$ benzalkonium chloride (BC, positive control), or $31.25 \mu \mathrm{g} / \mathrm{cm}^{2} \mathrm{PS}-\mathrm{NH}_{2}$ for $24 \mathrm{~h}$. Effects on cells were assessed using the (A) MTS assay, and (B) LDH release assay. Results expressed as percentages (MTS assay) of untreated control RHE or as fold induction levels of control RHE (LDH assay). For the MTS assay and the LDH release assay one experiment was performed each, error bars represent the standard deviation of technical replicates.

\section{Figure 3}

Cytotoxicity of surface-modified polystyrene nanoparticles in A549 cells, THP-1 cells and A549/THP-1 co-cultures. 
Cells were exposed to increasing concentrations $(0,1,10,25,50$ and $100 \mu \mathrm{g} / \mathrm{ml})$ of PS$\mathrm{COOH}$ (filled symbols) or PS-NH $\mathrm{N}_{2}$ (open symbols) for $24 \mathrm{~h}$. Effects on cells were assessed using the (A) ATP assay, (B) MTS assay, and (C) LDH release assay. Results of the ATP and MTS assays expressed as percentages of untreated control; LDH release was normalized to maximum activity after Triton X-100 treatment and expressed as percentages of untreated control. Mean values of 3 independent experiments each with standard deviation are shown. Curves are regressions over mean values.

\section{Figure 4}

Cytotoxicity of surface-modified polystyrene nanoparticles in Caco-2 cells and differentiated Caco-2 cells.

Cells were exposed to increasing concentrations $(0,1,10,25,50$ and $100 \mu \mathrm{g} / \mathrm{ml})$ of PS$\mathrm{COOH}$ (filled symbols) or PS- $\mathrm{NH}_{2}$ (open symbols) for $24 \mathrm{~h}$. Effects on cells were assessed using the (A) ATP assay, (B) MTS assay, and (C) TEER assay. Results were expressed as percentages of untreated control. For the naïve Caco-2 cells (diamonds) 3 independent experiments were performed each; mean values with standard deviation are shown. For the MTS assay and TEER measurement on differentiated Caco-2 cells (triangles) one experiment of each is shown. Curves are regressions over mean values.

\section{Figure 5}

Cytotoxicity of surface-modified polystyrene nanoparticles in CD34-derived dendritic cells (CD34-DCs).

Cells were exposed to increasing concentrations $(0,1,10,25,50$ and $100 \mu \mathrm{g} / \mathrm{ml})$ of PS$\mathrm{COOH}$ (filled symbols) or PS- $\mathrm{NH}_{2}$ (open symbols) for $24 \mathrm{~h}$. Effects on cells were assessed using the (A) ATP assay, (B) MTS assay, and (C) LDH release assay. Results were expressed as percentages (ATP -A- and MTS -B- assays) of non-treated cells or as fold induction levels of control cells (LDH assay). Mean values of 3 independent experiments each with standard deviation are shown. Curves are regressions over mean values. 
A

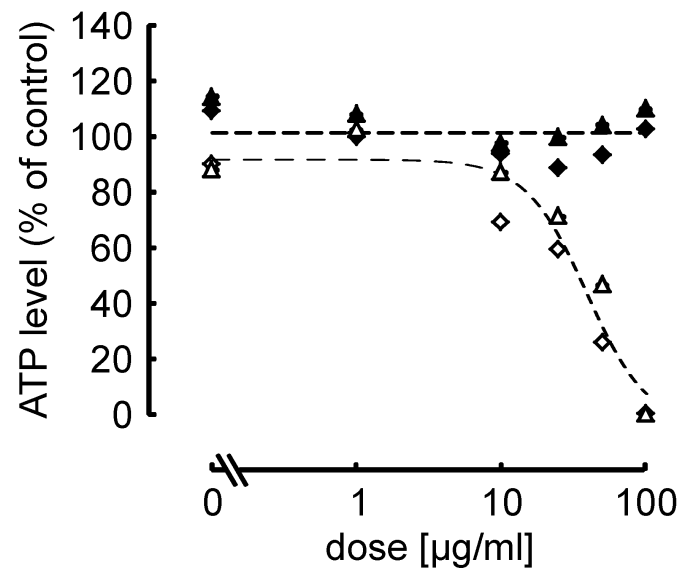

C

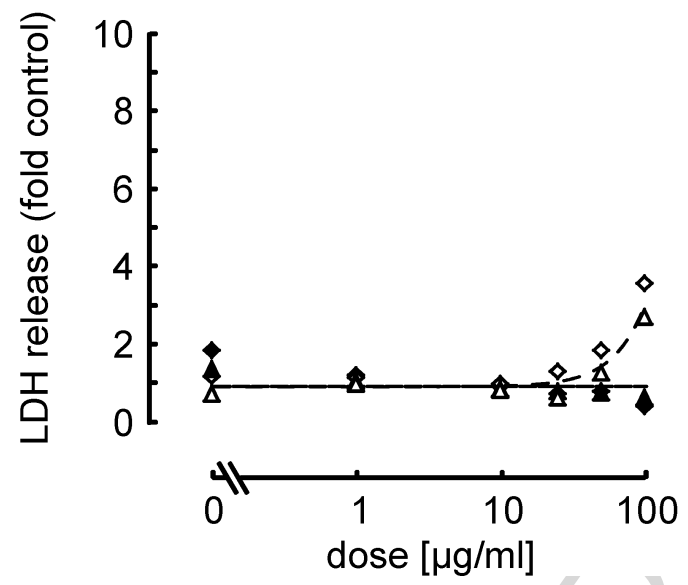

B

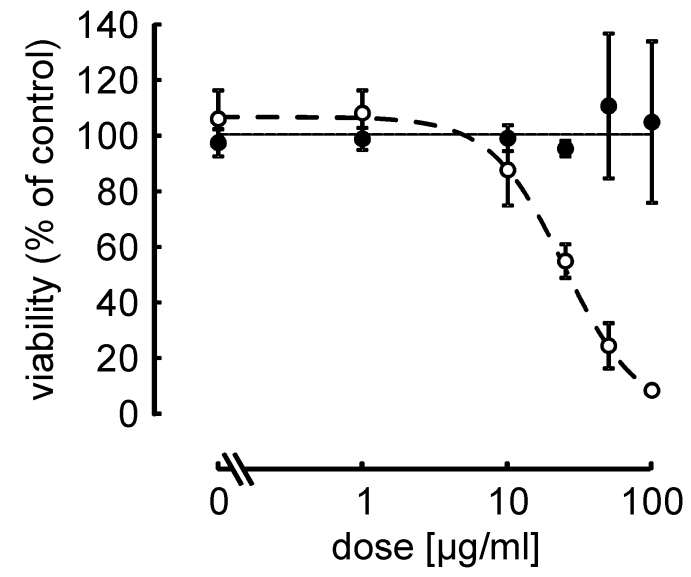

Fig. 1 
A

B
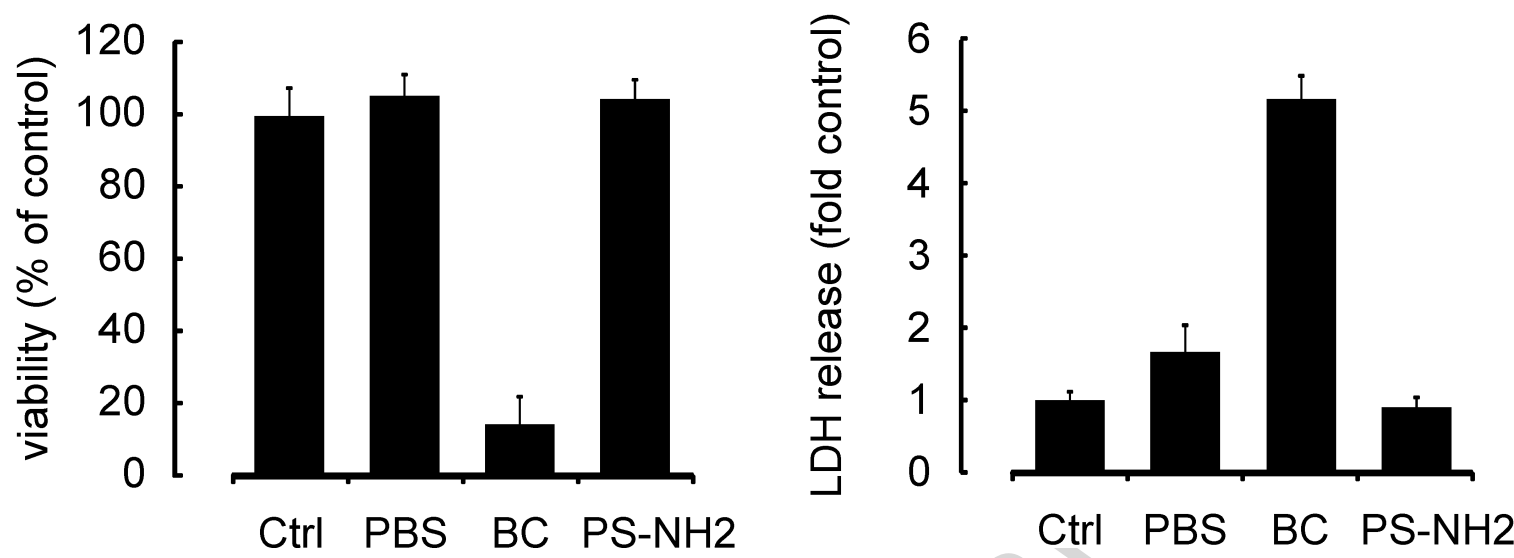

Fig. 2 
A

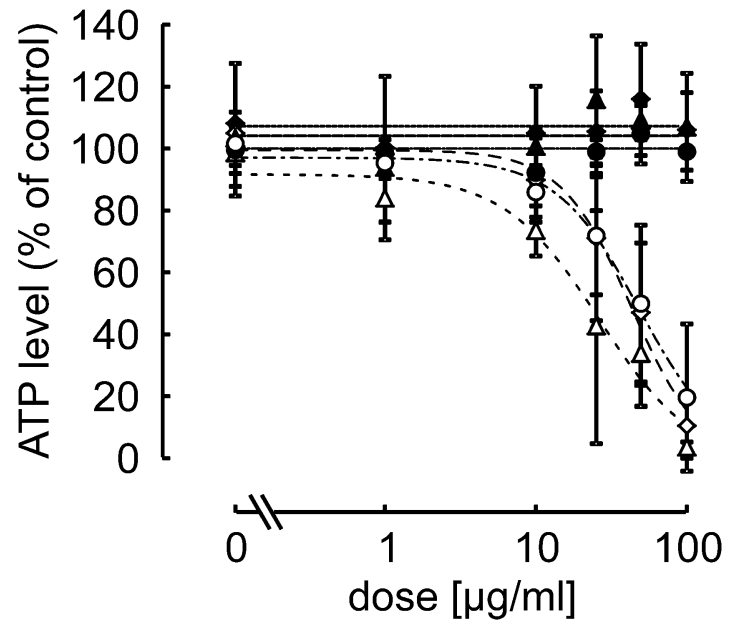

C
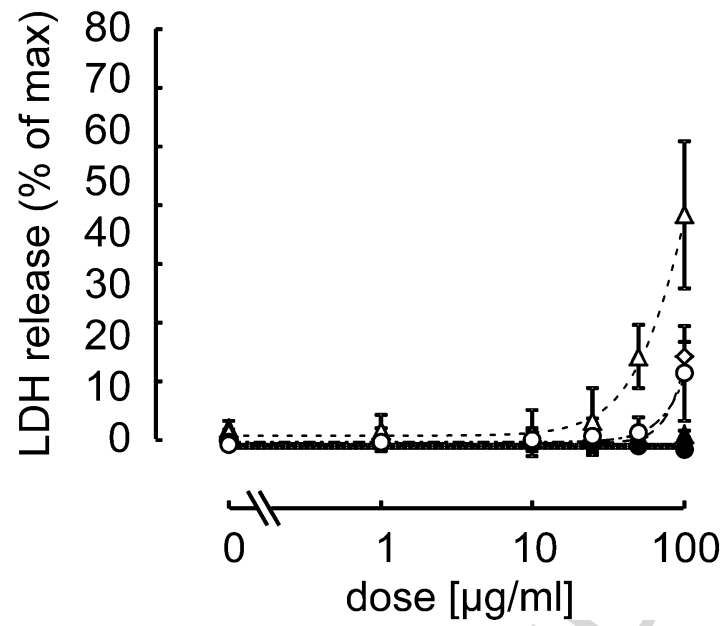

B

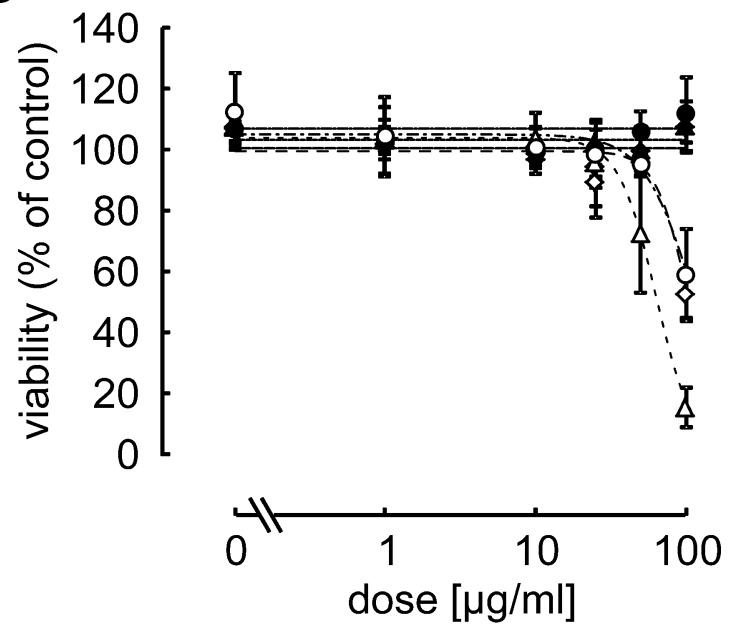

Fig. 3 
A

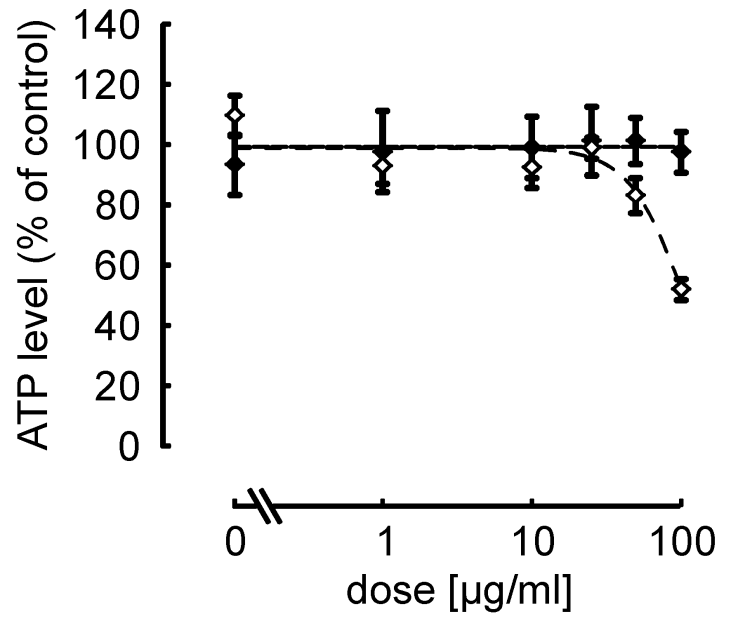

C

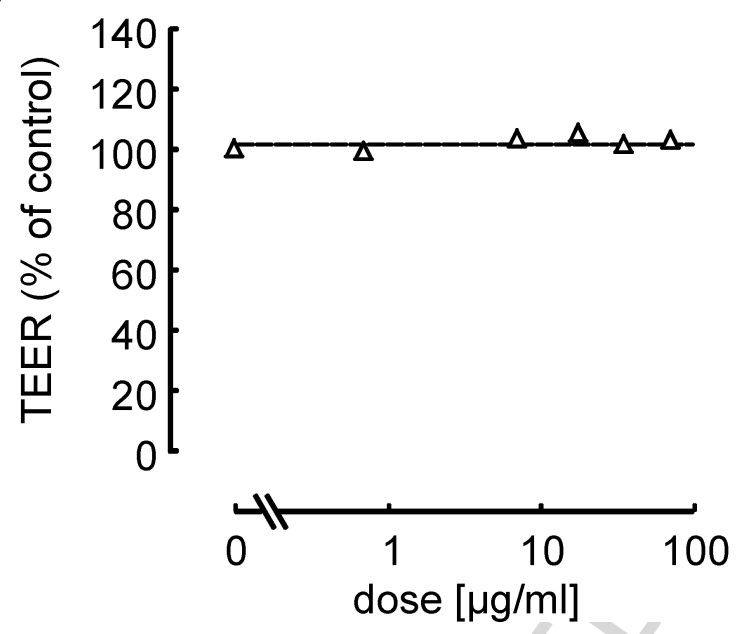

B

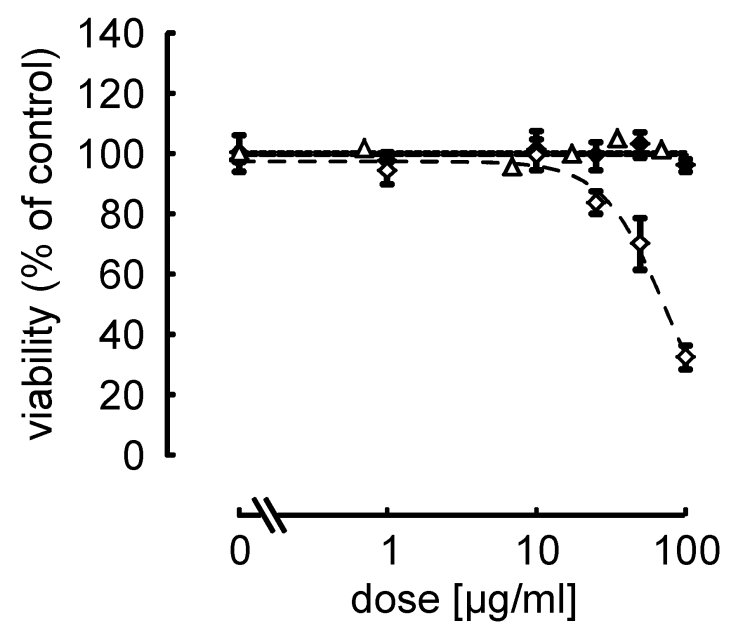

Fig. 4 
A

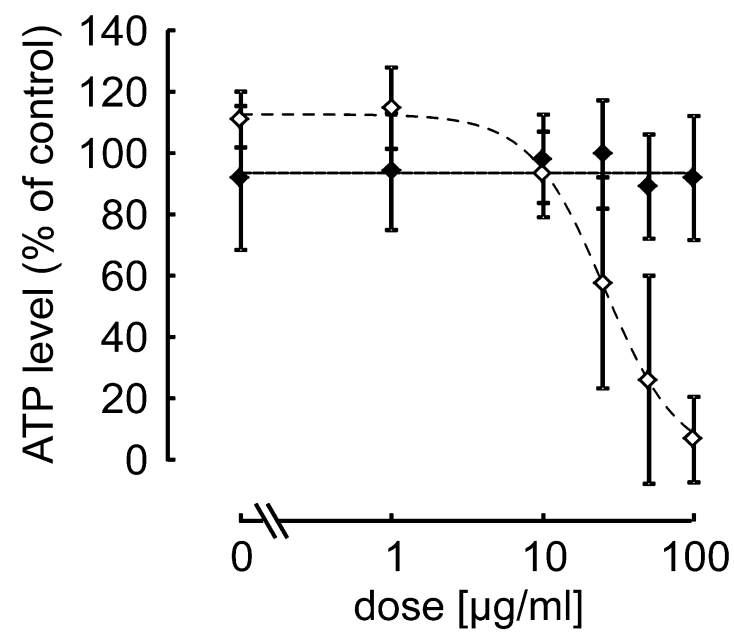

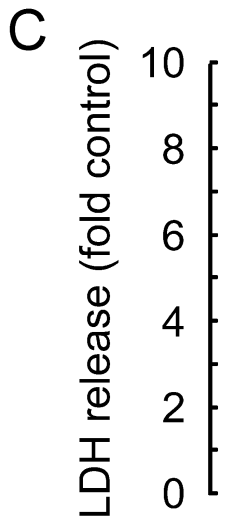

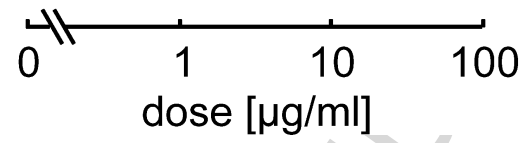

B

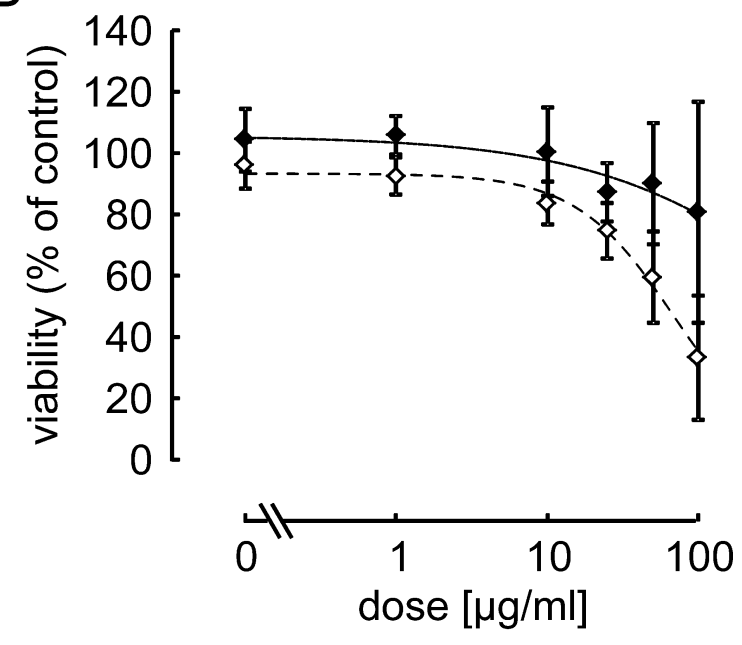

Fig. 5 


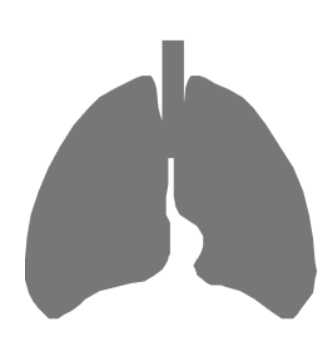

inhalation

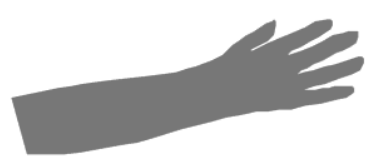

dermal

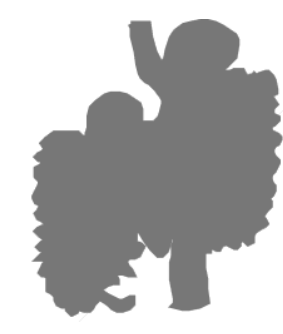

oral

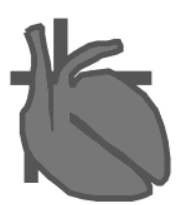

blood
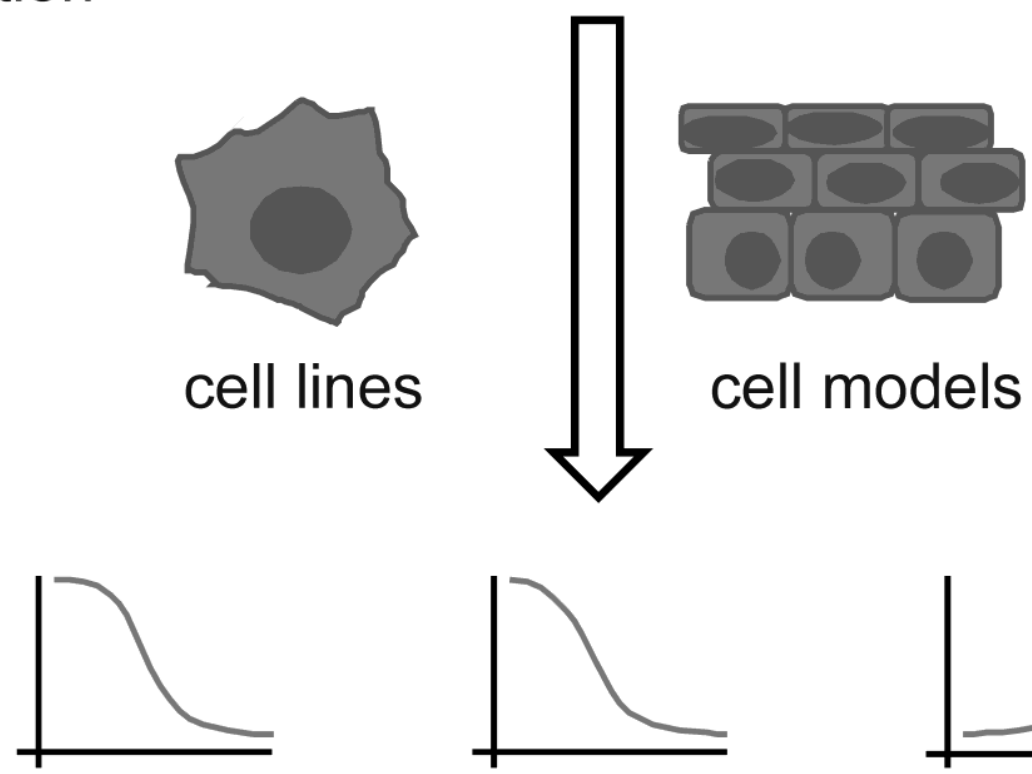

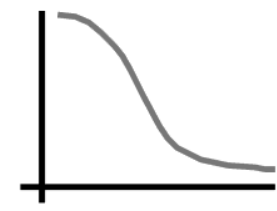

ATP >

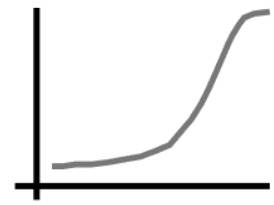

LDH

Graphical abstract 


\section{A guide to nanosafety testing: considerations on cytotoxicity testing in different cell models}

Christian Riebeling ${ }^{1^{*}}$, Jean-Pascal Piret ${ }^{2^{*}}$, Bénédicte Trouiller ${ }^{3^{*}}$, Inge Nelissen ${ }^{4^{*}}$, Christelle Saout ${ }^{2}$, Olivier Toussaint ${ }^{2 \dagger}$, Andrea Haase ${ }^{1 \#}$

1) German Federal Institute for Risk Assessment (BfR), Department of Chemical and Product Safety, Berlin, Germany

2) University of Namur, Namur Research Institute for Life Sciences (NARILIS), Namur Nanosafety Center (NNC), Research Unit in Cellular Biology (URBC), Namur, Belgium 3) Institut National de l'Environnement Industriel et de Risques (INERIS), Experimental Toxicology Unit, Verneuil-en-Halatte, France

4) Flemish Institute for Technological Research (VITO), Environmental Risk and Health Unit, Mol, Belgium

${ }^{*}$ authors contributed equally

"Correspondence should be addressed to:

Dr. Andrea Haase

German Federal Institute for Risk Assessment (BfR)

Department of Chemical and Product Safety

Max-Dohrn-Strasse 8-10

10589 Berlin

Germany

phone: $\quad$ +4930184123423

fax: $\quad+49301841263423$

e-mail: andrea.haase@bfr.bund.de 


\section{Highlights}

1) Comparison of three cytotoxicity assays covering different biological principles

2) Comparison of ten cell models, i.e. cell lines, primary and complex cell models

3) Cell models are representative of the main routes of exposure to NPs

4) MTS assay was applicable to all, and was the most robust and reproducible assay

5) PS-COOH and PS-NH2 are useful negative and positive controls for cytotoxicity testing

"include 3 to 5 bullet points (maximum 85 characters, including spaces, per bullet point)" 